\title{
Reduced levels of convalescent neutralizing antibodies against SARS- CoV-2 B.1+L249S+E484K lineage
}

Diego A. Álvarez-Díaz ${ }^{*}$, Katherine Laiton-Donato ${ }^{1}$, Orlando Alfredo Torres-García ${ }^{2}$, Hector Alejandro Ruiz-Moreno ${ }^{1}$, Carlos Franco-Muñoz ${ }^{1,3}$, Maria Angie Beltran ${ }^{4}$, Marcela Mercado-Reyes ${ }^{1}$, Miguel Germán Rueda ${ }^{4}$, Ana Luisa Muñoz ${ }^{4,5^{*}}$

*These authors contributed equally.

\section{Author names and affiliations}

${ }^{1}$ Grupo de Genómica de Microorganismos Emergentes. Dirección de Investigación en Salud Pública, Instituto Nacional de Salud, Bogotá, Colombia.

${ }^{2}$ Faculty of Veterinary Medicine and Zootechnics, Universidad Antonio Nariño, Bogotá, Colombia.

${ }^{3}$ Grupo de Parasitología. Dirección de Investigación en Salud Pública, Instituto Nacional de Salud, Bogotá, Colombia.

${ }^{4}$ Fundación Banco Nacional de Sangre Hemolife, Bogotá, Colombia.

${ }^{5}$ Faculty of Science, Universidad Antonio Nariño, Bogotá, Colombia.

\section{Corresponding author}

Ana L Muñoz, Calle 23 \#116-31, Bodega 26, Bogotá, Colombia. Tel.: (+57 1) 7428124, E-mail: ana.munoz@hemolfeamerica.org

\section{HIGHLIGHTS}

? The E484K mutation in B.1+L249S+E484K appears not to affect the viral titer

[? Sensitivity of lineages without E484K mutation to neutralizing antibodies did not change

[? B.1+L249S+E484K lineage shows a reduction in its neutralizing capacity 


\section{ABSTRACT}

The E484K mutation at the SARS-CoV-2 Spike protein emerged independently in different variants around the world, probably as part of the ongoing adaptation of the virus to the human host, and has been widely associated with immune escape from neutralizing antibodies generated during previous infection or vaccination. In this work, the B.1+L249S+E484K lineage was isolated along with A.1, B.1.420 and B.1.111 SARS-CoV-2 lineages without the E484K mutation and the neutralizing titer of convalescent sera was compared using microneutralization assays. While no significant differences in the neutralizing antibody titers were found between $A 1$ and $B$ lineages without the E484K mutation, the neutralizing titers against B.1+L249S+E484K were 1.5, 1.9, 2.1, and 1.3-fold lower than against A.1, B.1.420, B.1.111-I, and B.1.111-II, respectively. However, molecular epidemiological data indicate that there is no increase in the transmissibility rate associated with this new lineage. Hence, although the evidence provided in this study support a Variant of Interest Status (VOI) for the B1+L249S+E484K lineage, enhanced laboratory characterization of this particular lineage and other emerging lineages with the E484K mutation should be carried out in individuals with immunity acquired by natural infection and vaccination. This study accentuated the capability of new variants with the E484K mutation to be resistant to neutralization by humoral immunity, and therefore the need to intensify surveillance programs.

\section{KEYWORDS}

COVID-19, Spike protein, Neutralizing antibodies, SARS-CoV-2 lineages, E484K mutation, Variant of Interest. 


\section{INTRODUCTION}

The pandemic of coronavirus disease 2019 (COVID-19) caused by severe acute respiratory syndrome coronavirus 2 (SARS-CoV-2) is rapidly changing. It is known that, following the infection, a polyclonal set of antibodies against SARS-CoV-2 proteins are produced, playing a crucial role in the acquired immunity against this virus. In particular, antibodies generated against the spike (S) protein are well known for their ability to compromise the host cell receptor binding and membrane fusion. This leads to blocking the entry of the virus into the host cell, and these antibodies are called neutralizing antibodies (1).

However, the adaptive process of SARS-CoV-2 to human host has resulted in the emergence of antigenically distinct and/or more virulent variants with evidence of reduced neutralization by antibodies generated from natural infection or vaccination; a matter of great importance in the process of selecting the antigenic component in vaccine formulation (2).

Whereby, the US government interagency group and Centers for Disease Control and Prevention $(C D C)$, proposed a hierarchical variant classification scheme with three classes of SARS-CoV-2 variants, namely, Variant of Interest (VOI), Variant of Concern (VOC) and, Variant of High Consequence (VOHC). Here, the presence of substitutions or combinations of substitutions at the Spike (S) protein, associated with reduced neutralization by antibodies generated from previous infection or vaccination, is one of the critical attributes to classify as VOI. The escalation to VOC depends on scientific evidence such as laboratory confirmation of significant escape to neutralizing antibodies and/or epidemiological data supporting increased transmissibility and disease severity. Finally, although no VOHC have been identified so far, it is expected that a VOHC has clear evidence of diagnostic failure, a significant reduction in vaccine effectiveness, therapeutics, and more severe clinical disease (3).

In February 2020, in the early stages of the pandemic, the B.1 lineage emerged in Europe with the characteristic D614G mutation in the S protein, which distinguishes it from the $A$ and $B$ ancestral lineages (4). This lineage rapidly became the most prevalent (5), even in South America, where the first introduced cases corresponded to the A.1 lineage with the conserved D614 position (6), and several studies provided evidence on the association of this mutation with fitness advantages without significant impacts on the severity of infection or neutralizing antibody titers $(4,7,8)$.

Later, the E484K mutation in the S protein emerged independently in different VOI and VOC, probably by evolutionary convergence $(9,10)$ and was associated with reduced antibody neutralization (11), antiviral drug resistance (12) and a slightly enhancing of ACE2 affinity (13). In fact, the E484K mutation is a significant genetic marker, and its presence is considered enough to qualify a variant for VOI status (14).

In line with this, SARS-CoV-2 genomic surveillance at Colombia's National Institute of Health (INS), identified a highly divergent SARS-CoV-2 lineage characterized by the presence of 21 substitutions, including two amino acid changes in the S protein (L249S and E484K). For this reason, it was proposed for lineage reassignment (B.1+L249S+E484K) and laboratory evaluation of neutralizing antibodies (15). 
Several methods have been documented for the assessment of neutralizing antibodies against SARS-CoV-2, among them, pseudovirus-based protocols have proved well correlation with neutralization titers (16-19), however, the gold standard is the in vitro neutralization using replication-competent virus because their sensitivity is higher and allow the evaluation of aspects such as viral fitness and the impact of mutations in proteins other than Spike $(20,21)$.

Thus, in this work, we determined the neutralizing antibody titers in convalescent sera against B.1+L249S+E484K and three lineages (A.1, B.1.420, and B.1.111) without the E484K mutation using microneutralization assays to evaluate the potential impact of the E484K mutation in this new lineage on the sensitivity to convalescent neutralizing antibodies.

\section{MATERIAL AND METHODS}

\subsection{Human subject collection}

The samples were collected between March 2020 and February 2021; all subjects enrolled in this research responded voluntarily to an informed consent formulary previously approved by the Ethics Committee of Colombian National Health Institute (CEMIN)-10-2020. This study was conducted in compliance with ethical principles of the Declaration of Helsinki and to the conditions provided by the Ministry of Health - Colombia.

\subsection{Cells}

African green monkey kidney Vero E6 cells (ATCC CRL-1586 ${ }^{\text {TM }}$ ) were used to propagate the SARSCoV-2 isolates and the neutralization assays. Cells were cultured in Dulbecco's Modified Eagle's medium (DMEM) (Lonza ${ }^{\circledR}$, Catalog No. 12-604Q) supplemented with $10 \%$ (v/v) heat-inactivated fetal bovine serum (FBS) (Biowest ${ }^{\oplus}$, Catalog No. S18b-500), and $100 \mathrm{U} / \mathrm{mL}$ penicillin and streptomycin (Lonza ${ }^{\circledR}$, Catalog No. $17-602 \mathrm{~F}$ ) at $37^{\circ} \mathrm{C}$ with $5 \% \mathrm{CO}_{2}$.

\subsection{Sample selection and virus isolation}

Nasopharyngeal swab specimens from volunteer participants from the five Colombian regions were collected based on the representativeness and virologic criteria, following the Pan American Health Organization (PAHO) guidance for SARS-CoV-2 samples selection (22). Samples with positive real-time RT-PCR for SARS-CoV-2 and PANGO lineage assignment (23), following the nanopore ARTIC network protocol (24), were selected for virus isolation in Vero E6 monolayers.

For this, each sample was diluted 1:2 with DMEM supplemented with 2\% FBS. The dilutions were filtered through a 0.2 um membrane and used to inoculate $7.5 \times 10^{5}$ Vero E6 cells seeded the previous day in T-25 flasks. The inoculum was incubated for 1 hour at $37{ }^{\circ} \mathrm{C}$ in a $5 \% \mathrm{CO}_{2}$ environment. Finally, $4 \mathrm{~mL}$ of DMEM medium supplemented with $4 \%$ FBS were added, and virusinduced cytopathic effect (CPE) was examined daily for up to 7 days. When CPE was observed, culture supernatant was collected and centrifuged at $300 \times \mathrm{xg}$ for $5 \mathrm{~min}$ at room temperature, 
distributed in aliquots of 500uL, and stored in liquid nitrogen (25). All the procedures handling the infected cell cultures were held in a biocontainment laboratory.

\subsection{Phylogenetic analysis}

We recovered 1856 sequences from SARS-CoV-2 infections in Colombia from the GISAID database. The sequence dataset was aligned using the MAFFT software v7 $(26,27)$. The alignment was manually curated to remove UTRs and correct possible misalignments. Sequences with genome coverage lower than 90 percent were removed, as well as redundant identical sequences. The final aligned dataset contained 400 sequences with representatives from each lineage circulating in Colombia by July 2021 in each region. A maximum likelihood tree reconstruction was performed with the GTR+F+I+G4 nucleotide substitution model using IQTREE. The substitution model was selected according to the lowest BIC score using IQTREE modelfinder (26). Branch support was estimated with 1000 replicates of an SH-like approximate likelihood ratio test (SH-aLRT), and 1000 ultrafast bootstrap replicates.

\subsection{Virus titration}

Virus titers were determined by the Reed and Muench tissue culture infective dose $\left(T C I D_{50}\right)$ endpoint method (28), after three independent assays. Briefly, for titration, $1.5 \times 10^{5}$ Vero E6 cells/mL were plated into 96-well plates 16 to 24 hours before infection. Then, the virus stock was diluted serially from $10-1$ to $10-10$, and $100 \mu \mathrm{L}$ of each dilution was added to the respective well (Eight replicates were performed for each dilution) and incubated in $5 \% \mathrm{CO}_{2}$ at $37 \mathrm{C}$ for $72 \mathrm{~h}$. Finally, the $\mathrm{TCID}_{50}$ endpoint was determined.

\subsection{Microneutralization and binding antibody assays}

Serum samples were obtained from five convalescent donors with COVID-19 diagnosis confirmed by real time RT-PCR on nasopharyngeal swab specimens at least 15 days before inclusion. A serum bank specimen from 2019 was used as a pre-pandemic negative control. Additionally, SARS-CoV2 IgG anti-Nucleocapsid antibodies detection on the Allinity ci series (Abbott, Chicago,IL, USA) was done as screening, where relative light units (RLU) $>1.4$ were interpreted as positive. Serum samples were conserved at $-20^{\circ} \mathrm{C}$ until the moment of the analysis.

The microneutralization assay was adapted from the methodology published by Algaissi $A$ and Hashem A (25). Briefly, the presence of neutralizing antibodies was assessed by means of eight 2fold dilutions (1:20 to 1:2560) of heated inactivated serum samples tested against $2000 \mathrm{TCI}_{50}$ of each variant virus stock in supplemented DMEM with $2 \% \mathrm{FBS}$ for one $\mathrm{h}$ at $37 \mathrm{C}$. After that, the suspension was transferred on a monolayer of $1.5 \times 10^{4}$ Vero $\mathrm{E} 6$ and incubated at $37^{\circ} \mathrm{C}$ with $5 \%$ $\mathrm{CO}_{2}$ for 3 days. The neutralizing titer was determined as the highest serum dilution at which no CPE was observed under inverted microscope Primovert (Zeiss). Each sample was tested five times, in three independent tests. 


\subsection{Statistical analysis}

For analysis of differences in serum neutralizing antibody titers, data were log transformed and one-way ANOVA using the DMS multiple comparison correction was used for columnated data while two-way ANOVA using the Tukey multiple comparison correction was used for grouped data. Results with $p$ values $<0.05$ were considered significant. The data were analyzed in GraphPad Prism (v9.0.2).

\section{RESULTS}

\subsection{Successful isolation of SARS-CoV-2 lineages with and without the Spike E484K mutation}

Five SARS-CoV-2 isolates representing four different PANGO lineages were selected for the MN assays (Table 1). Remarkably, the isolate EPI_ISL_1092007 currently assigned to the B.1 lineage (PANGO v.3.1.7 2021-07-09) was proposed for lineage reassignment (B.1+L249S+E484K) and laboratory evaluation of neutralizing antibodies in convalescent sera (15). The remaining isolates represented SARS-CoV-2 lineages without the E484K mutation as follows; EPI_ISL_49816 representing the $A 1$ lineage, it was the only isolate without the characteristic D614G mutation in the $\mathrm{S}$ protein obtained in this study. The other isolates correspond to the B.1.420 (EPI_ISL_52696 B.1.420) and B.1.111 (EPI_ISL_526971 and EPI_ISL_794659) lineages. Regarding B.1.111 isolates, although both share the mutation pattern characteristic of the B.1.111 lineage (Spike D614G, NS3 Q57H and NSP12 P323L), several divergent genome wide mutations were observed between those isolates, for example, EPI_ISL_794659 have two additional mutations at the S protein (Spike T859I and W152R) (Table 1).

Viral stocks of the five isolates titrated by the Reed and Muench method yielded similar titers reaching $10^{5} \mathrm{TCID}_{50} / \mathrm{mL}$ (Table 1). Thus, the E484K mutation in B.1+L249S+E484K appears not to affect the viral titer in Vero E6 cells (Table 2) or the virus ability to induce a cytopathic effect (Fig. $1 \mathrm{~A})$. 


\subsection{Phylogenetic analysis reveals B.1.111 sublineages}

Given the close lineage assignment of four isolates as lineage B.1 or sublineages B.1.111 and B.1.420, we performed a maximum likelihood phylogenetic analysis to confirm their lineage and placement within a tree with 400 representative sequences from each lineage circulating in Colombia by July 2021 (Fig. 1B). The lineage assignment of the five isolates was confirmed in the phylogenetic reconstruction. The isolates B.1.111-I and B.1.111-II share a lineage designation but different mutation profiles (Table 1). The major number of mutations in B.1.111-II indicates a greater divergence consistent with the sampling date and the expected accumulation of mutations during the pandemic, as observed in the tree (Fig. 1B). The isolate B.1.111-I is located close to the node defining the B.1.111 lineage, while B.1.111-II is placed in a monophyletic group along with more B.1.111 sequences containing the Spike mutation W152R, which is not as divergent as B.1+L249S+E484K. Furthermore, in line with the previous report, the B.1+L249S+E484K sample genome is grouped in a sublineage of the B.1.111 lineage (15).

\subsection{Reduced neutralization antibody titers against B1+L249S+E484K in convalescent sera}

We initially characterized five convalescent COVID-19 patients previously diagnosed with SARSCoV-2 infection by RT-qPCR, sampled at a median of 90d (range 30-150d) post- onset of symptoms, using SARS-CoV2 IgG anti-Nucleocapsid antibodies detection kit (Abbott, Chicago,IL, USA). All individuals demonstrated greater reactivity to nucleocapsid protein than pre-pandemic control, which was comparable to the obtained MN titers (Table 3). Thus, neutralizing antibodies correlated with nucleocapsid binding antibodies (Fig. 2C).

Then, the neutralizing capacity of these sera was evaluated using eight 2-fold serially diluted sera (1:20 to 1:12560) against A.1, B.1.420, B.1.111, and B.1+L249S+E484K lineages to determine the MN50 titer of each serum sample. Results from three independent assays evidenced differences between the neutralization titers obtained against the five isolates. Specifically, the neutralizing titers against B.1+L249S+E484K were 1.5, 1.9, 2.1 and 1.3-fold lower than against A.1, B.1.420, B.1.111-I and B.1.111-II, respectively (Fig. 2A). Furthermore, the neutralizing titers for the B.1.111II variant were 1.6-fold lower in relation to the variant B.1.111.I ( $\mathrm{P}<0.0001$ ) (Fig. 2B). Finally, no significant differences between neutralizing antibody titers were observed between $A 1$ and $B$ lineages without E484K mutation (Figure 2B). 


\subsection{Molecular epidemiological data support a decrease of B.1+L249S+E484K cases between March-2020 and July-2021}

The spatiotemporal distribution pattern of the most representative SARS-CoV-2 lineages in Colombia between March 2020 and July 2021 shows a significant country level decrease of cases associated with the lineages evaluated in this study (Fig. 3). By January 2021, B.1.111 was predominant and widely distributed across the five Colombian regions, followed by $B .1$ and B.1.420 (Fig. 3A and 3B). This scenario changed by July 2021, with a notable decrease in these lineages by two- to three-fold, which were displaced by P.1 and B.1.621. Remarkably, B.1+L249S+E484K was exclusively distributed in the Caribbean region between March-2020 and July-2021, and the decline of cases by the end of this period suggests a limited community transmission (Fig. 3A and 3B).

\section{DISCUSSION}

The ongoing global surveillance programs have revealed the emergence of variants harboring mutations in Spike, the principal target of neutralizing antibodies. This study shows the neutralizing activity of natural infection-elicited antibodies against four SARS-CoV-2 lineages, including B.1+L249S+E484K.

The E484K substitution, located at the receptor-binding domain (RBD), is continuously and independently occurring in emerging SARS-CoV-2 VOCs and VOIs across all over the world (3). This phenomenon is probably an example of selective immune pressure and receptor-binding affinity optimization as part of the ongoing adaptation of the virus to the human host $(9,29)$.

Our results suggest that E484K mutation in B.1+L249S+E484K does not affect the viral titer, however it reduces antibody neutralization, when compared to the A.1, B.1.420, B.1.111 lineages, all of them without the E484K mutation. In agreement with previous reports, the single E484K mutation was associated with reduced neutralizing activity of convalescent and post-vaccination (Pfizer-BioNTech) sera, against replication-competent SARS-CoV-2, and pseudoviruses (11). Moreover, the resistance to neutralizing antibodies in other lineages carrying this mutation has been described in B.1.1.7, B.1.351, and P.1 $(9,30)$. It is essential to clarify that it has been reported that variants with the E484K mutation have no alterations in its stability or in host cell entry (31).

We also observed a slightly higher neutralizing antibody titer against B.1.111-I compared with B.1.111-II (Fig. 2); this could be explained by the presence of two additional mutations in the $S$ protein, T859I and W152R (Table 1), because the presence of mutations at the same positions have been reported independently in the VOIs B.1.526 (lota) (32) and B.1.429 (33), respectively.

Remarkably, the phylogenetic maximum likelihood phylogenetic tree reconstructed in this study grouped the isolates B.1+L249S+E484K and B.1.111-II in the same clade (Fig. 1B), which evidences the importance of phylogenetic analysis in understanding phylogenetic relationships beyond the PANGOLIN assignment in the face of the emergence of variants with particular mutations. 
While the $\mathrm{MN}$ assays unequivocally evidenced reduced neutralization antibody titers against $\mathrm{B} 1+\mathrm{L} 249 \mathrm{~S}+\mathrm{E} 484 \mathrm{~K}$ in convalescent sera (Fig. 2A), molecular epidemiological data indicate that there is no increase in the transmissibility rate associated with this new lineage (Figure 3 ). Hence, the $\mathrm{B} 1+\mathrm{L} 249 \mathrm{~S}+\mathrm{E} 484 \mathrm{~K}$ lineage must be regarded as a VOI at least for Colombia, furthermore, surveillance of this particular lineage and other emerging lineages with the E484K mutation should be carried out in individuals with immunity acquired by natural infection and vaccination.

A limitation of this study is the small number of convalescent samples tested, and the absence of samples from vaccinated individuals, future work with more subjects, including vaccinated individuals will help to determine the clinical impact of this mutation, as well as its role in the effectiveness of currently approved vaccine strategies.

\section{CONCLUSION}

These results suggest the emergence of a new SARS-CoV-2 lineage with the ability to escape from neutralizing humoral immunity. As the virus continues to adapt to the human host, the accumulation of these mutations on aspects such as the immune response against natural infection or vaccination is unknown. Consequently, it is necessary the intensification of the genomic surveillance programs and the refinement of protocols for the evaluation of point and multiple mutations and their association with the escape from neutralizing antibodies.

\section{REFERENCES}

1. Yang Y, Du L. SARS-CoV-2 spike protein: a key target for eliciting persistent neutralizing antibodies. Signal Transduct Target Ther 202161 [Internet]. 2021 Feb 26 [cited $2021 \mathrm{Sep}$ 8];6(1):1-3. Available from: https://www.nature.com/articles/s41392-021-00523-5

2. Harvey WT, Carabelli AM, Jackson B, Gupta RK, Thomson EC, Harrison EM, et al. SARS-CoV2 variants, spike mutations and immune escape. Nat Rev Microbiol [Internet]. $2021 \mathrm{Jul} 1$ [cited 2021 Sep 8];19(7):1. Available from: /pmc/articles/PMC8167834/

3. Variants and Genomic Surveillance for SARS-CoV-2 | CDC [Internet]. [cited 2021 Sep 10]. Available from: https://www.cdc.gov/coronavirus/2019-ncov/variants/index.html

4. Volz E, Hill V, McCrone JT, Price A, Jorgensen D, O'Toole Á, et al. Evaluating the Effects of SARS-CoV-2 Spike Mutation D614G on Transmissibility and Pathogenicity. Cell [Internet]. 2021 Jan 7 [cited 2021 Sep 8];184(1):64-75.e11. Available from: http://www.cell.com/article/S0092867420315373/fulltext

5. B K, WM F, S G, H Y, J T, W A, et al. Tracking Changes in SARS-CoV-2 Spike: Evidence that D614G Increases Infectivity of the COVID-19 Virus. Cell [Internet]. 2020 Aug 20 [cited 2021 Sep 8];182(4):812-827.e19. Available from: https://pubmed.ncbi.nlm.nih.gov/32697968/ 
It is made available under a CC-BY-NC-ND 4.0 International license .

6. Franco-Muñoz C, Álvarez-Díaz DA, Laiton-Donato K, Wiesner M, Escandón P, Usme-Ciro JA, et al. Substitutions in Spike and Nucleocapsid proteins of SARS-CoV-2 circulating in South America. Infect Genet Evol [Internet]. 2020 Nov 1 [cited 2021 Sep 8];85:104557. Available from: https://www.sciencedirect.com/science/article/abs/pii/S1567134820303889?via\%3Dihub

7. Plante JA, Liu Y, Liu J, Xia H, Johnson BA, Lokugamage KG, et al. Spike mutation D614G alters SARS-CoV-2 fitness. Nat 20205927852 [Internet]. 2020 Oct 26 [cited $2021 \mathrm{Sep}$ 8];592(7852):116-21. Available from: https://www.nature.com/articles/s41586-020-28953

8. $L Y, X W, K E P, C T-T, T P N, Y$, et al. Structural and Functional Analysis of the D614G SARSCoV-2 Spike Protein Variant. Cell [Internet]. 2020 Oct 29 [cited 2021 Sep 10];183(3):739751.e8. Available from: https://pubmed.ncbi.nlm.nih.gov/32991842/

9. Ferrareze PAG, Franceschi VB, Mayer A de M, Caldana GD, Zimerman RA, Thompson CE. E484K as an innovative phylogenetic event for viral evolution: Genomic analysis of the E484K spike mutation in SARS-CoV-2 lineages from Brazil. Infect Genet Evol [Internet]. 2021 Sep 1 [cited 2021 Sep 8];93:104941. Available from: https://www.sciencedirect.com/science/article/abs/pii/S1567134821002380

10. SARS-CoV-2 variants of concern as of 6 September 2021 [Internet]. [cited 2021 Sep 8]. Available from: https://www.ecdc.europa.eu/en/covid-19/variants-concern

11. Jangra S, Ye C, Rathnasinghe R, Stadlbauer D, Alshammary H, Amoako AA, et al. SARS-CoV-2 spike E484K mutation reduces antibody neutralisation. The Lancet Microbe [Internet]. 2021 Jul 1 [cited 2021 Sep 8];2(7):e283-4. Available from: http://www.thelancet.com/article/S2666524721000689/fulltext

12. FACT SHEET FOR HEALTH CARE PROVIDERS EMERGENCY USE AUTHORIZATION (EUA) OF BAMLANIVIMAB AND ETESEVIMAB AUTHORIZED USE [Internet]. 2021 [cited 2021 Sep 8]. Available from: https://www.fda.gov/media/151719/download

13. C L, K de K, R K, JHG L. Experimental Evidence for Enhanced Receptor Binding by Rapidly Spreading SARS-CoV-2 Variants. J Mol Biol [Internet]. 2021 Jul 23 [cited 2021 Sep 8];433(15). Available from: https://pubmed.ncbi.nlm.nih.gov/34023401/

14. Boehm E, Kronig I, Neher RA, Eckerle I, Vetter P, Kaiser L. Novel SARS-CoV-2 variants: the pandemics within the pandemic. Clin Microbiol Infect [Internet]. 2021 Aug 1 [cited 2021 Sep 8];27(8):1109-17. Available from: https://pubmed.ncbi.nlm.nih.gov/34015535/

15. Laiton-Donato K, Usme-Ciro JA, Franco-Muñoz C, Álvarez-Díaz DA, Ruiz-Moreno HA, RealesGonzález J, et al. Novel Highly Divergent SARS-CoV-2 Lineage With the Spike Substitutions L249S and E484K. Front Med [Internet]. 2021 Jun 28 [cited 2021 Sep 8];0:932. Available from:

https://www.frontiersin.org/articles/10.3389/fmed.2021.697605/full?\&utm_source=Email _to_authors_\&utm_medium=Email\&utm_content=T1_11.5e1_author\&utm_campaign=Em ail_publication\&field=\&journalName=Frontiers_in_Medicine\&id=697605

16. Riepler L, Rössler A, Falch A, Volland A, Borena W, Laer D von, et al. Comparison of Four SARS-CoV-2 Neutralization Assays. Vaccines 2021, Vol 9, Page 13 [Internet]. 2020 Dec 28 [cited 2021 Sep 8];9(1):13. Available from: https://www.mdpi.com/2076-393X/9/1/13/htm 
17. Almahboub SA, Algaissi A, Alfaleh MA, ElAssouli M-Z, Hashem AM. Evaluation of Neutralizing Antibodies Against Highly Pathogenic Coronaviruses: A Detailed Protocol for a Rapid Evaluation of Neutralizing Antibodies Using Vesicular Stomatitis Virus PseudovirusBased Assay. Front Microbiol [Internet]. 2020 Sep 4 [cited 2021 Sep 8];11. Available from: /pmc/articles/PMC7498578/

18. Donofrio G, Franceschi V, Macchi F, Russo L, Rocci A, Marchica V, et al. A Simplified SARSCoV-2 Pseudovirus Neutralization Assay. Vaccines 2021, Vol 9, Page 389 [Internet]. 2021 Apr 15 [cited 2021 Sep 8];9(4):389. Available from: https://www.mdpi.com/2076393X/9/4/389/htm

19. Neerukonda SN, Vassell R, Herrup R, Liu S, Wang T, Takeda K, et al. Establishment of a wellcharacterized SARS-CoV-2 lentiviral pseudovirus neutralization assay using 293T cells with stable expression of ACE2 and TMPRSS2. PLoS One [Internet]. 2021 Mar 1 [cited 2021 Sep 8];16(3):e0248348. Available from:

https://journals.plos.org/plosone/article?id=10.1371/journal.pone.0248348

20. Deshpande GR, Sapkal GN, Tilekar BN, Yadav PD, Gurav Y, Gaikwad S, et al. Neutralizing antibody responses to SARS-CoV-2 in COVID-19 patients. Indian J Med Res [Internet]. 2020 Jul 1 [cited 2021 Sep 8];152(1-2):82. Available from: /pmc/articles/PMC7853248/

21. Legros V, Denolly S, Vogrig M, Boson B, Siret E, Rigaill J, et al. A longitudinal study of SARSCoV-2-infected patients reveals a high correlation between neutralizing antibodies and COVID-19 severity. Cell Mol Immunol 2020182 [Internet]. 2021 Jan 6 [cited 2021 Sep 8];18(2):318-27. Available from: https://www.nature.com/articles/s41423-020-00588-2

22. Laiton-Donato K, Franco-Muñoz C, Álvarez-Díaz DA, Ruiz-Moreno HA, Usme-Ciro JA, Prada DA, et al. Characterization of the emerging B.1.621 variant of interest of SARS-CoV-2. Infect Genet Evol [Internet]. 2021 Nov 1 [cited 2021 Sep 8];95:105038. Available from: https://www.sciencedirect.com/science/article/pii/S1567134821003361

23. Rambaut A, Holmes EC, O'Toole Á, Hill V, McCrone JT, Ruis C, et al. A dynamic nomenclature proposal for SARS-CoV-2 lineages to assist genomic epidemiology. Nat Microbiol 2020511 [Internet]. 2020 Jul 15 [cited 2021 Sep 8];5(11):1403-7. Available from: https://www.nature.com/articles/s41564-020-0770-5

24. K L-D, CJ V-A, JA U-C, C F-M, DA Á-D, LS V-A, et al. Genomic Epidemiology of Severe Acute Respiratory Syndrome Coronavirus 2, Colombia. Emerg Infect Dis [Internet]. 2020 Dec 1 [cited 2021 Sep 8];26(12):2854-62. Available from: https://pubmed.ncbi.nlm.nih.gov/33219646/

25. A A, AM H. Evaluation of MERS-CoV Neutralizing Antibodies in Sera Using Live Virus Microneutralization Assay. Methods Mol Biol [Internet]. 2020 [cited 2021 Sep 8];2099:10716. Available from: https://pubmed.ncbi.nlm.nih.gov/31883091/

26. K K, J R, KD Y. MAFFT online service: multiple sequence alignment, interactive sequence choice and visualization. Brief Bioinform [Internet]. 2019 Mar 27 [cited $2021 \mathrm{Sep}$ 8];20(4):1160-6. Available from: https://pubmed.ncbi.nlm.nih.gov/28968734/

27. MAFFT - a multiple sequence alignment program [Internet]. [cited 2021 Sep 10]. Available from: https://mafft.cbrc.jp/alignment/software/closelyrelatedviralgenomes.html 
28. REED L, MUENCH H. A SIMPLE METHOD OF ESTIMATING FIFTY PER CENT ENDPOINTS. Am J Epidemiol [Internet]. 1938 May 1 [cited 2021 Sep 8];27(3):493-7. Available from: https://academic.oup.com/aje/article/27/3/493/99616

29. Resende PC, Gräf T, Paixão ACD, Appolinario L, Lopes RS, Mendonça AC da F, et al. A Potential SARS-CoV-2 Variant of Interest (VOI) Harboring Mutation E484K in the Spike Protein Was Identified within Lineage B.1.1.33 Circulating in Brazil. Viruses 2021, Vol 13, Page 724 [Internet]. 2021 Apr 21 [cited 2021 Sep 8];13(5):724. Available from: https://www.mdpi.com/1999-4915/13/5/724/htm

30. D P, T B, L G, F G-B, I S, F P, et al. Sensitivity of infectious SARS-CoV-2 B.1.1.7 and B.1.351 variants to neutralizing antibodies. Nat Med [Internet]. 2021 May 1 [cited 2021 Sep 8];27(5):917-24. Available from: https://pubmed.ncbi.nlm.nih.gov/33772244/

31. $\mathrm{M} \mathrm{H}, \mathrm{P} \mathrm{A}, \mathrm{R} \mathrm{G}, \mathrm{A} \mathrm{S}, \mathrm{BF} \mathrm{H}, \mathrm{AS} \mathrm{H}$, et al. SARS-CoV-2 variants B.1.351 and P.1 escape from neutralizing antibodies. Cell [Internet]. 2021 Apr 29 [cited 2021 Sep 8];184(9):23842393.e12. Available from: https://pubmed.ncbi.nlm.nih.gov/33794143/

32. Annavajhala MK, Mohri H, Wang P, Nair M, Zucker JE, Sheng Z, et al. Emergence and expansion of SARS-CoV-2 B.1.526 after identification in New York. Nat 2021 [Internet]. 2021 Aug 24 [cited 2021 Sep 10];1-9. Available from: https://www.nature.com/articles/s41586-021-03908-2

33. McCallum M, Bassi J, de Marco A, Chen A, Walls AC, Di lulio J, et al. SARS-CoV-2 immune evasion by the B.1.427/B.1.429 variant of concern. Science (80- ) [Internet]. 2021 Aug 6 [cited 2021 Sep 10];373(6555):648-54. Available from:

https://www.science.org/doi/full/10.1126/science.abi7994

\section{ACKNOWLEDGEMENTS}

Authors gratefully acknowledge Rotary International for equipment's donation. Authors also acknowledge all the contributing scientists publishing viral sequences in GISAID database, as well as its administrators for supporting rapid sharing of genomic data.

\section{FUNDING SOURCES}

This work was supported by funds from the Fundación Banco Nacional de Sangre Hemolife (CEMIN-10-2020) and the Instituto Nacional de Salud, Bogotá D.C, Colombia (CORHUCO project).

\section{DECLARATION OF INTEREST}

The authors declare no conflicts of interest.

\section{AUTHORS' CONTRIBUTIONS}


medRxiv preprint doi: https://doi.org/10.1101/2021.09.13.21263430; this version posted September 16, 2021. The copyright holder for this preprint (which was not certified by peer review) is the author/funder, who has granted medRxiv a license to display the preprint in perpetuity.

It is made available under a CC-BY-NC-ND 4.0 International license .

Diego A. Álvarez-Díaz: Conceptualization, Methodology, Investigation, Formal analysis, Data Curation, Writing - Original Draft. Katherine Laiton-Donato: Investigation, Data Curation, Formal analysis. Orlando Alfredo Torres-García: Validation, Formal analysis, Data Curation. Carlos FrancoMuñoz: Data Curation. Hector Alejandro Ruiz: Software, Formal analysis, Writing - Original Draft. Maria Angie Beltran: Investigation. Marcela Mercado-Reyes: Conceptualization, Methodology, Funding acquisition, Supervision. Miguel Germán Rueda: Conceptualization, Methodology, Funding acquisition, Supervision. Ana Luisa Muñoz: Conceptualization, Methodology, Investigation, Formal analysis, Data Curation, Writing - Original Draft.

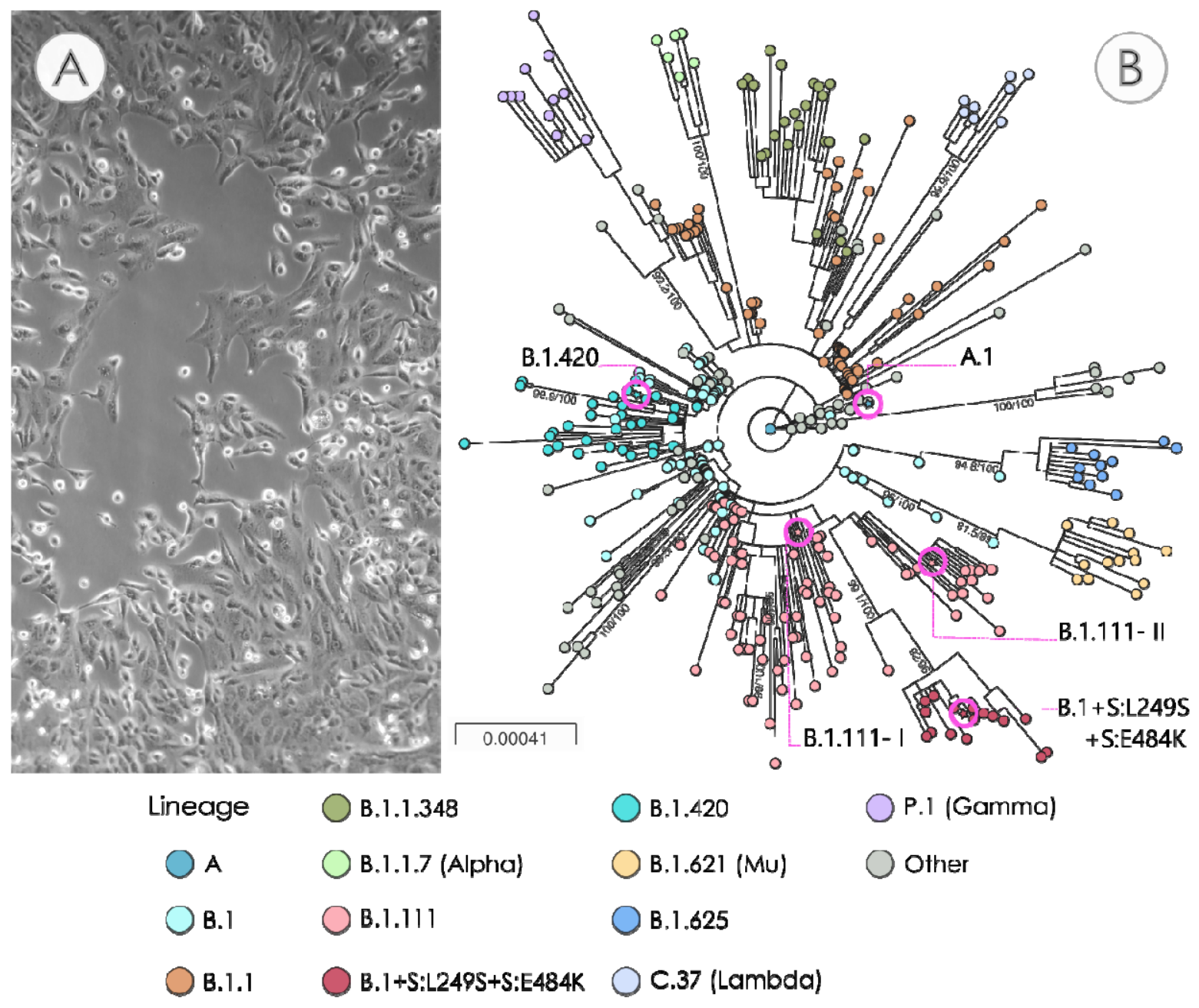

Figure 1. Phylogeny of SARS-CoV-2 lineages selected for the MN assays. A.) Representative image of Vero E6 cells infected with SARS-CoV-2. B.) Maximum likelihood phylogeny of SARS-CoV-2 representative lineages by July 2021 . The tree was reconstructed by maximum likelihood with the estimated GTR+F+I+G4 nucleotide substitution model for the dataset of 400 genomes. The scale 
medRxiv preprint doi: https://doi.org/10.1101/2021.09.13.21263430; this version posted September 16, 2021. The copyright holder for this preprint (which was not certified by peer review) is the author/funder, who has granted medRxiv a license to display the preprint in perpetuity.

It is made available under a CC-BY-NC-ND 4.0 International license .

represents nucleotide substitutions per site. The interactive phylogeny and map are available at https://microreact.org/project/fNyvqQHycKrwPjKFMDo6xD/48df9688

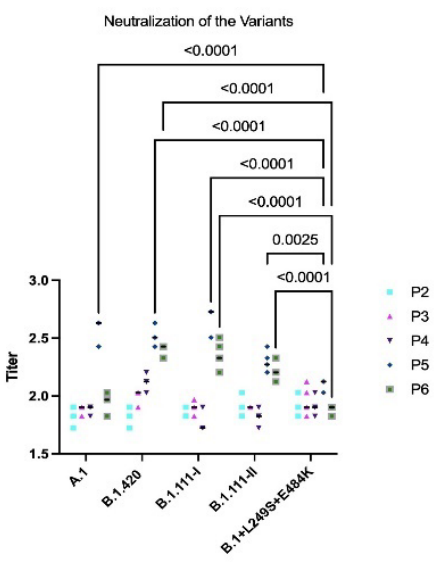

SARS-COV-2 Lineage

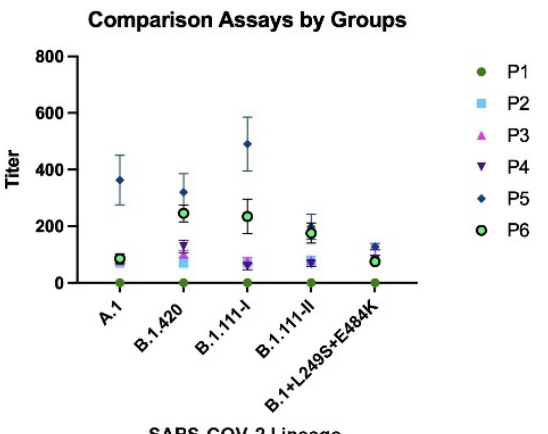

SARS-COV-2 Lineage

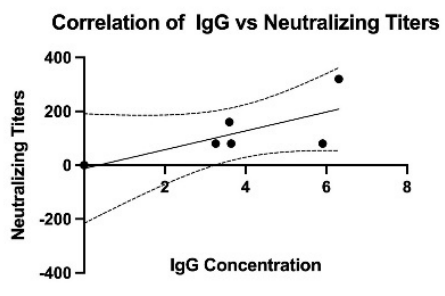

Figure 2. Neutralizing titers of convalescent sera against SARS-CoV-2 A.1, B.1.420, B.1.111, and B.1+L249S+E484K lineages. Panel A. Correlation of neutralizing titers against B.1+L249S+E484K in relation to SARS-CoV-2 lineages. Panel $B$. Neutralizing titers of convalescent sera against SARSCoV-2 A.1, B.1.420, B.1.111, and B.1+L249S+E484K lineages. Panel C. B1.111-I sublineage neutralization among convalescent COVID-19 patients and its correlation with SARS-CoV2 IgG antiNucleocapsid antibody titers 
medRxiv preprint doi: https://doi.org/10.1101/2021.09.13.21263430; this version posted September 16, 2021. The copyright holder for this preprint (which was not certified by peer review) is the author/funder, who has granted medRxiv a license to display the preprint in perpetuity.

It is made available under a CC-BY-NC-ND 4.0 International license .

March 2020 - January 2021

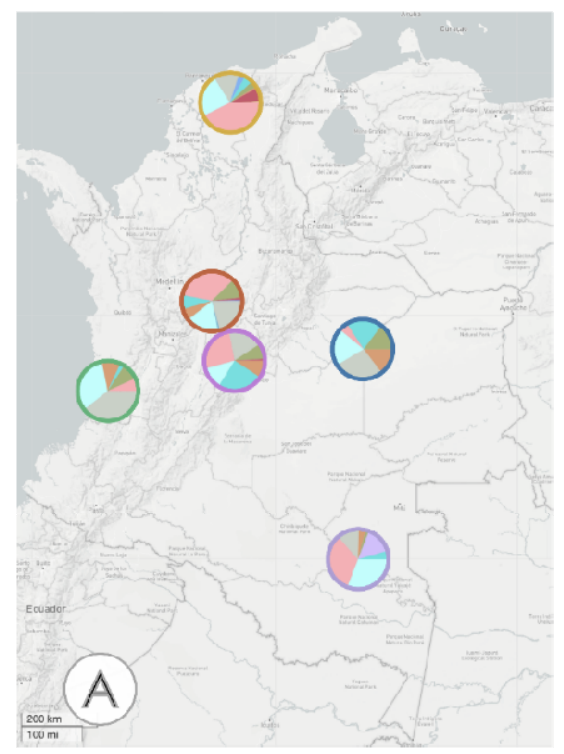

Regior

$\square$ Amazon

Andecn

Bogota D.C.

Carbobean
March 2020 - July 2021

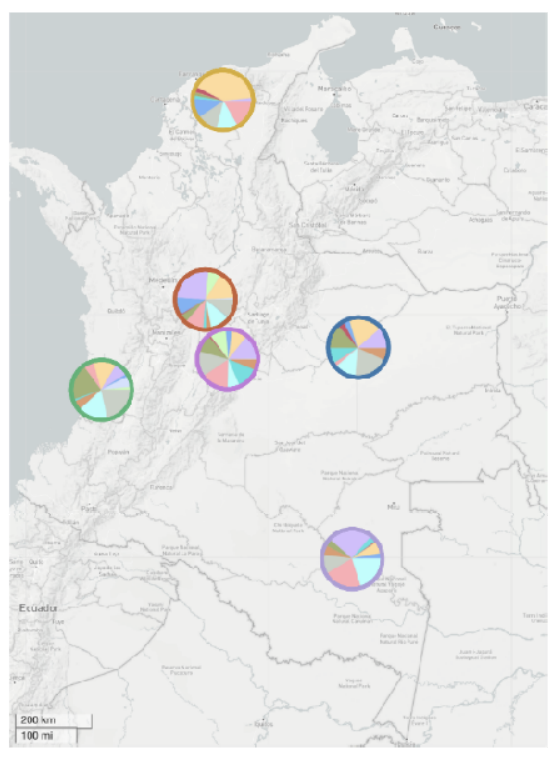

Lineage

B.1.1.348

O B.1.1.7 (Alpha)

B.1.111

\begin{abstract}
B.1.420
\end{abstract}
B.1.621

B.1.625

B.I

B.1.1

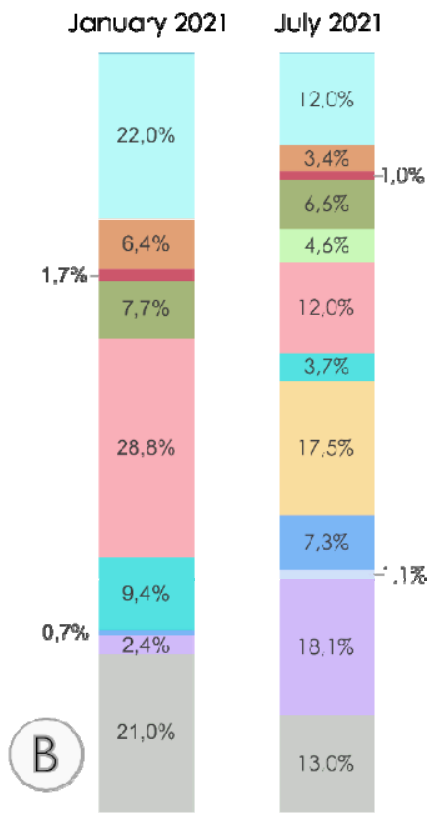

P.I Gumrnu;

Other

Figure 3. Spatiotemporal distribution of the most representative SARS-CoV-2 lineages in Colombia between January 20210 and July 2021. A.) SARS-CoV-2 lineage distribution in the five Colombian regions and Bogotá D.C March 2020 - January 20210 (left), and March-July 2021 (right). Ring colors represent the region. Interactive map available at https://microreact.org/project/sZ7jeqhSJ3bihFGBE1TVVG/0e4c2d4d. Country level SARS-CoV-2 percentages up to January 2021 (left), and up to July 2021 (right).

Table 1. Demographic data and genomic characteristics of the viral isolates selected for MN assays

\begin{tabular}{|l|l|l|l|l|l|l|}
\hline $\begin{array}{l}\text { Pango } \\
\text { Lineage* }\end{array}$ & $\begin{array}{l}\text { Isolate name } \\
\text { (GISAID AC. No.) }\end{array}$ & $\begin{array}{l}\text { Colombian } \\
\text { Region }\end{array}$ & AA Substitutions & $\begin{array}{l}\text { Disease } \\
\text { progression - } \\
\text { Outcome }\end{array}$ & $\begin{array}{l}\text { Patient } \\
\text { status }\end{array}$ & Symptoms \\
\hline A.1 & EPI_ISL_498169 & Andean & NS8 L84S, NSP1 G105S & Symptomatic & Live & Odynophagia \\
\hline B.1.420 & EPI_ISL_526969 & Bogotá DC & $\begin{array}{l}\text { Spike D614G, N A119T, } \\
\text { NSP12 A43S, NSP12 } \\
\text { P323L }\end{array}$ & Symptomatic & Live & Cough \\
\hline B.1.111-। & EPI_ISL_526971 & Bogotá DC & $\begin{array}{l}\text { Spike D614G, N M234|, } \\
\text { NS3 Q57H, NSP3 } \\
\text { S1285F, NSP12 P323L }\end{array}$ & Asymptomatic & Live & None \\
\hline
\end{tabular}


medRxiv preprint doi: https://doi.org/10.1101/2021.09.13.21263430; this version posted September 16, 2021. The copyright holder for this preprint (which was not certified by peer review) is the author/funder, who has granted medRxiv a license to display the preprint in perpetuity.

It is made available under a CC-BY-NC-ND 4.0 International license .

\begin{tabular}{|c|c|c|c|c|c|c|}
\hline B.1.111-II & EPI_ISL_794659 & Andean & $\begin{array}{l}\text { Spike D614G, Spike } \\
\text { T859I, Spike W152R, N } \\
\text { T205I, NS3 Q57H, NS3 } \\
\text { T223I, NSP1 I114T, NSP5 } \\
\text { K90R, NSP6 A136V, } \\
\text { NSP12 P323L }\end{array}$ & Hospitalized & Live & $\begin{array}{l}\text { Fever, } \\
\text { headache }\end{array}$ \\
\hline $\begin{array}{l}\text { B.1 } \\
\text { (B1.111+ } \\
\text { E484K) }\end{array}$ & EPI_ISL_1092007 & Caribbean & $\begin{array}{l}\text { Spike D614G, Spike } \\
\text { E484K, Spike L249S, N } \\
\text { T205I, NS3 Q57H, NS6 } \\
\text { I18V, NS7a L17F, NS7b } \\
\text { A15S, NSP5 V157L, } \\
\text { NSP12 P323L, NSP13 } \\
\text { L325F, NSP13 T153I, } \\
\text { NSP15 V314F, NSP16 } \\
\text { G213N }\end{array}$ & No Data & Live & $\begin{array}{c}\text { No data } \\
\text { available }\end{array}$ \\
\hline
\end{tabular}

Table 2. Viral titers of SARS-CoV-2 isolates estimated by the Reed and Muench method

\begin{tabular}{|l|l|}
\hline Lineage & Titer (TCID50 $/ \mathrm{mL})$ \\
\hline A.1 & $3.91 \times 10^{5} \mathrm{TCID}_{50} / \mathrm{mL}$ \\
\hline B.1.420 & $3.0 \times 10^{5} \mathrm{TCID}_{50} / \mathrm{mL}$ \\
\hline B.1.111-I & $3.2 \times 10^{5} \mathrm{TCID}_{50} / \mathrm{mL}$ \\
\hline B.1.111-II & $4.67 \times 10^{5} \mathrm{TCID}_{50} / \mathrm{mL}$ \\
\hline B.1+L249S+E484K & $4.53 \times 10^{5} \mathrm{TCI}_{50} / \mathrm{mL}$ \\
\hline
\end{tabular}

Table 3. Clinical data of convalescent subjects

\begin{tabular}{|c|c|c|c|}
\hline $\begin{array}{c}\text { Patient } \\
\text { Number }\end{array}$ & Symptoms & $\begin{array}{c}\text { IgG } \\
\text { (RLU) }\end{array}$ & $\begin{array}{c}\text { MN } \\
\text { titer against } \\
\text { Lineage } \\
\text { B.1.111-I }\end{array}$ \\
\hline 1 & NA & 0.275 & 0 \\
\hline 2 & $\begin{array}{c}\text { Adynamia, cough, rhinorrhea } \\
\text { breathing difficulties }\end{array}$ & 3.64 & $1: 80$ \\
\hline 3 & $\begin{array}{c}\text { anosmia and odynophagia } \\
\text { headache, adynamia, fever and } \\
\text { rhinorrhea, ageusia }\end{array}$ & 5.91 & $1: 80$ \\
\hline 4 & adynamia, rhinorrhea & 6.31 & $1: 320$ \\
\hline 5 & & & $1: 80$ \\
\hline 6 & cough, fever and odynophagia & 3.596 & $1: 160$ \\
\hline
\end{tabular}


medRxiv preprint doi: https://doi.org/10.1101/2021.09.13.21263430; this version posted September 16, 2021. The copyright holder for this preprint (which was not certified by peer review) is the author/funder, who has granted medRxiv a license to display the preprint in perpetuity.

It is made available under a CC-BY-NC-ND 4.0 International license . 


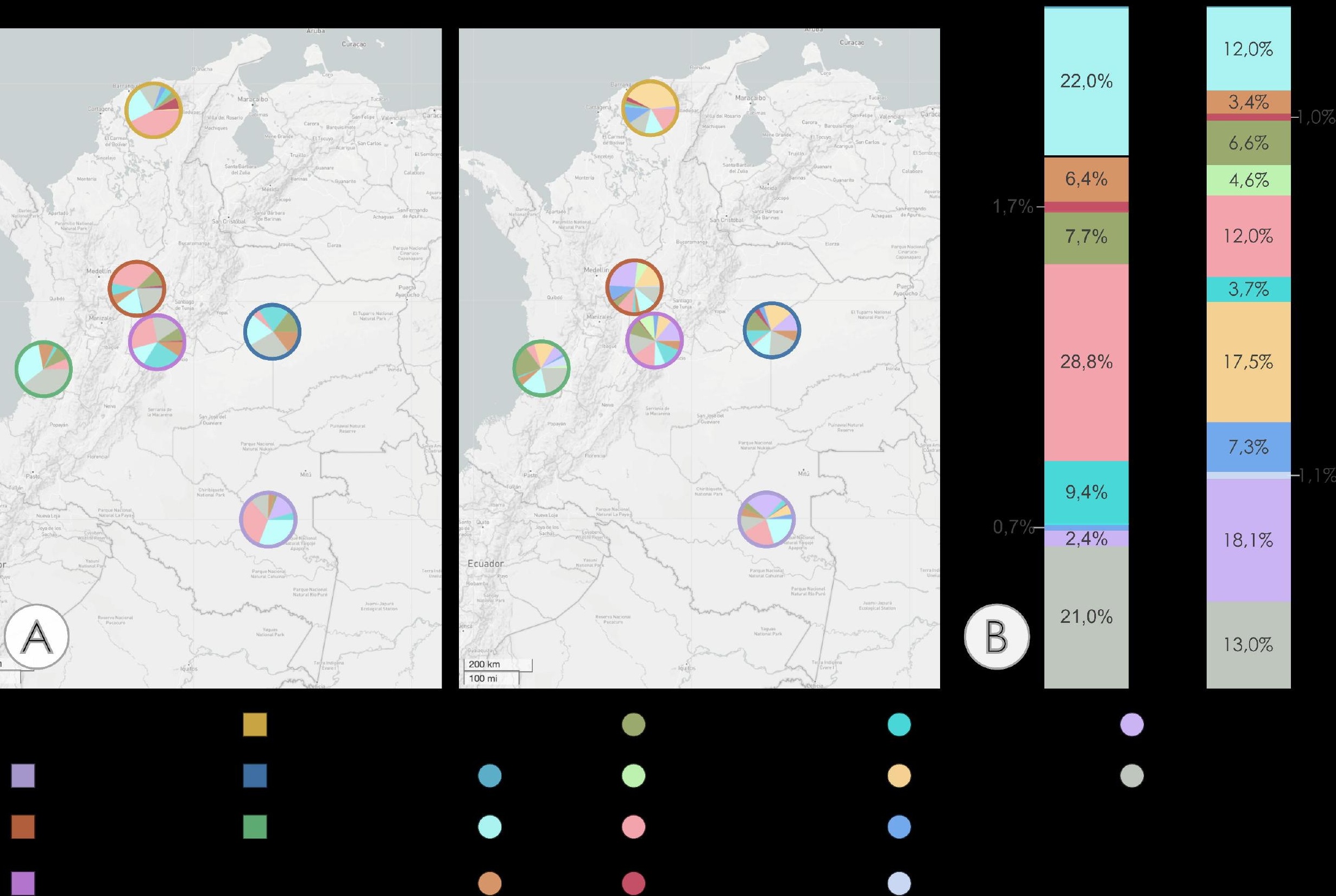




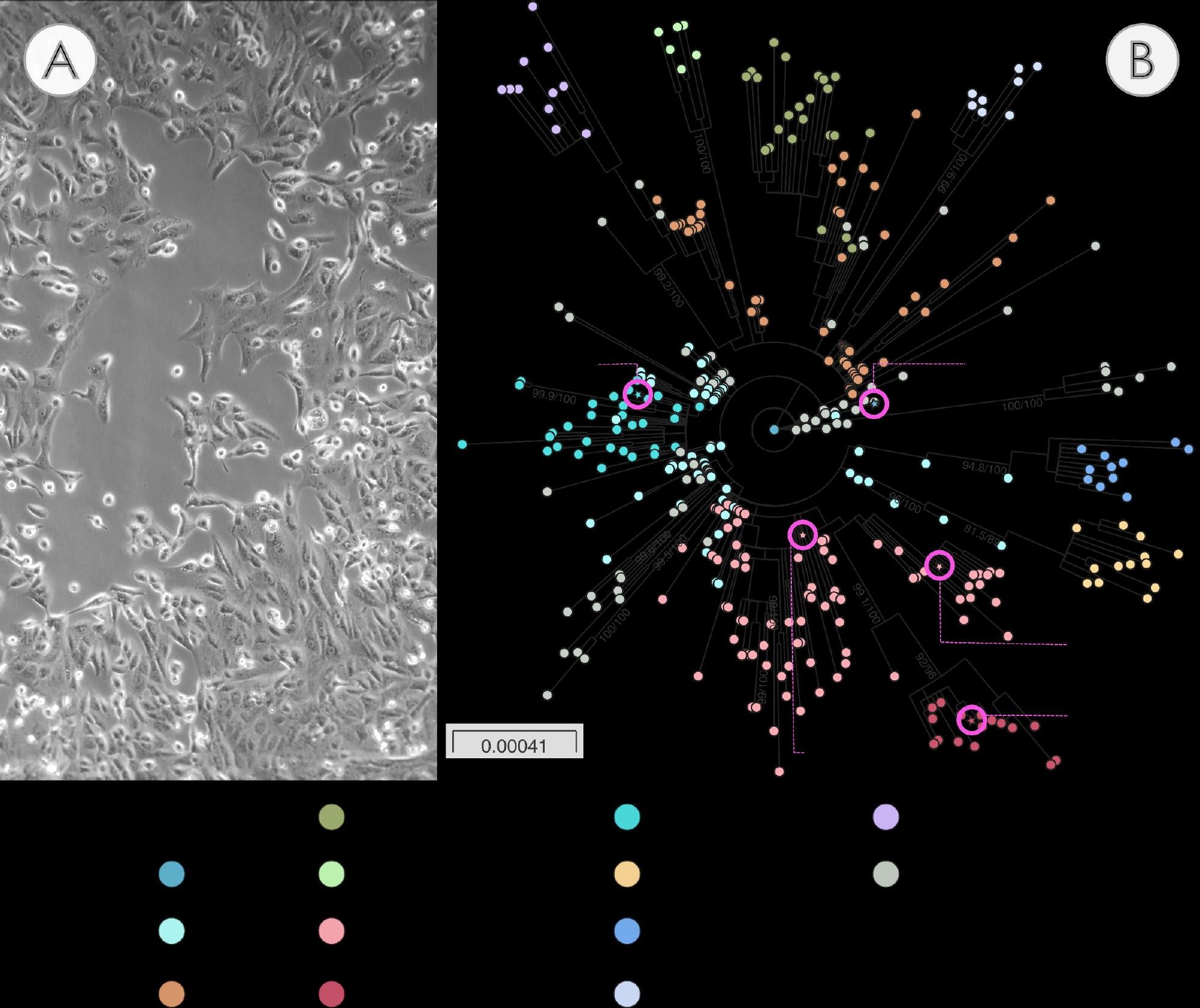


$<0.0001$

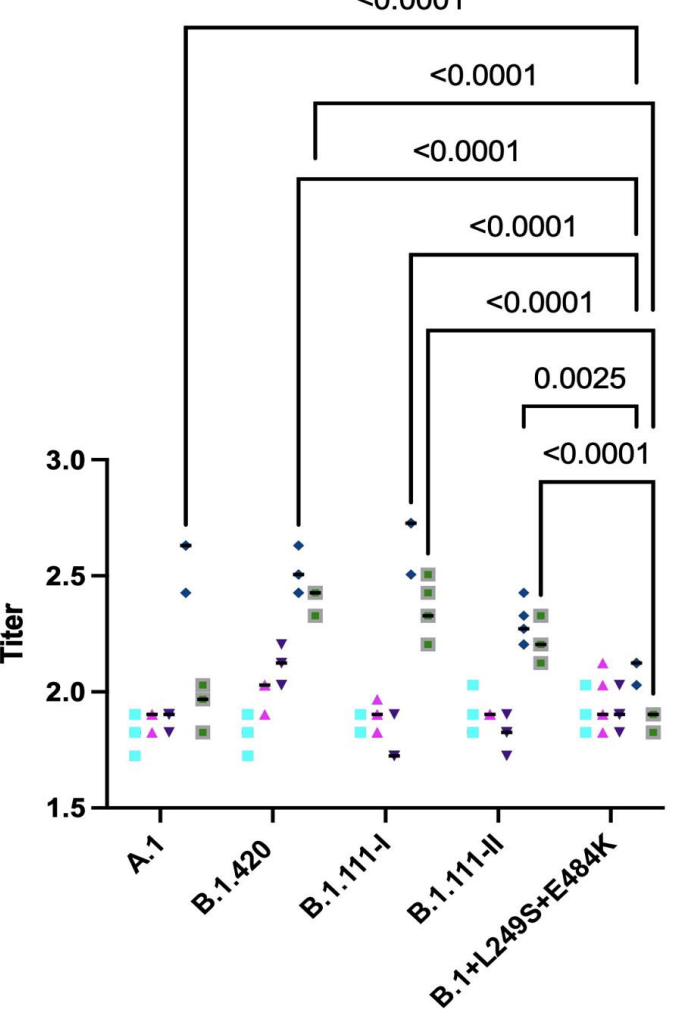

Comparison Assays by Groups
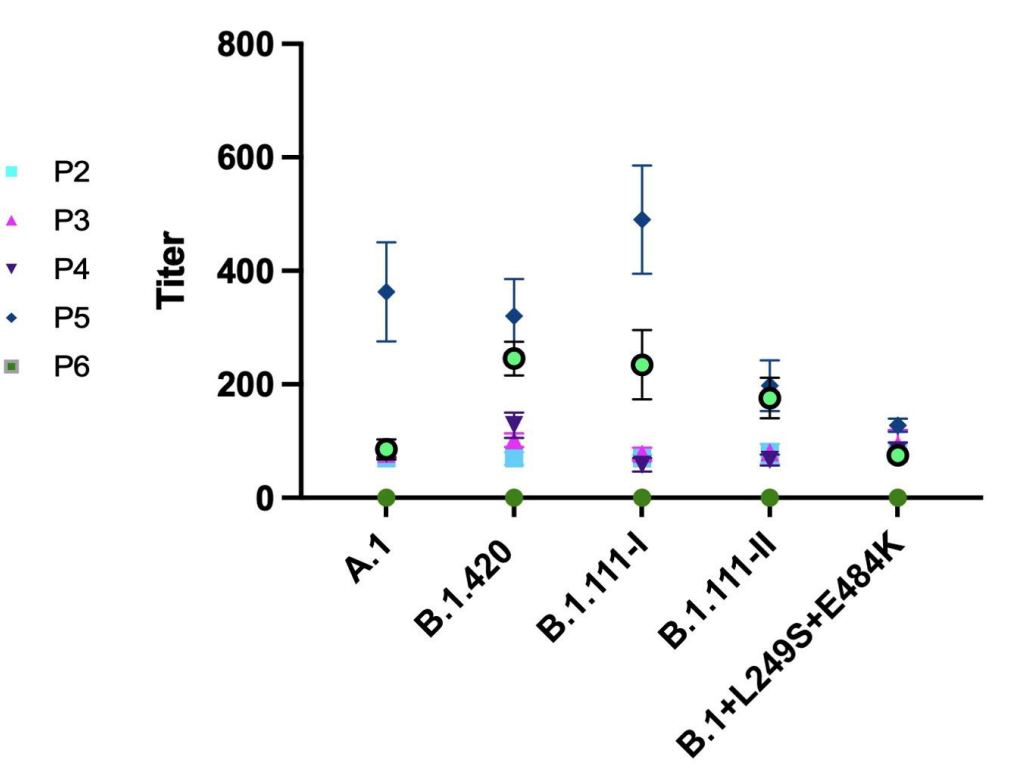

P1

P2

P3

$\checkmark \mathrm{P} 4$

- P5

- P6

Correlation of IgG vs Neutralizing Titers 